DOI 10.31558/2519-2949.2020.2.12

УДК 323.2:070(438) “19”

ORCID ID: https://orcid.org/0000-0001-5502-8367

Павлюх М. В., Національний університет «Львівська політехніка»

\title{
ПОЛІТИЧНА ПРОПАГАНДА ТА УКРАЇНСЬКА НАЦІОНАЛЬНА ІДЕЯ У ЧАСОПИСІ «УКРАЇНКА»
}

Проаналізовано головну тематику, жанри, статті часопису Союзу українок «Украӥнка». Досліджено матеріали, в яких жінки пропагували національну ідею, формували національну свідомість. Виокремлено головний тематичний контент патріотичного видання. Вивчено організацію роботи редакиії: рубрики та відділи. Подано головні публікаиії, в яких автори статей проводили політичну пропаганду проти польської окупаційної влади. 3 'ясовано, щуо видання Союзу Українок «Українка» формувало на своїх шпальтах жіночий патріотизм, будило політичну свідомість. Вказано головні напрями діяльності жіночої патріотичної організаиії Союзу Українок, яка діяла у Галичині першої половини ХХ століття.

Украӥнська начіональна ідея стала наскрізною ідеєю часопису. Орган патріотичної украӥнської жіночої організації Союзу Українок відіграв важливу роль у політичному житті Галичини периої половини ХХ століття, оскільки об'єднав патріотичних жінок у боротьбі за політичні свободи. Активність жінки-матері, жінки-берегині сімейного вогнища, жінки-патріотки підтримувалася виданням як головна ідейна компонента багатьох статей. Політична пропаганда на шпальтах видання «Украйнка» формувала громадську думку, насамперед, сільського жіноитва, яке не завжди мало змогу читати та навчатися.

У статті проаналізовані кілька важливих публікацій, які демонструють головні тематичні напрями. Видання «Украӥнка» пропагувало здоровий спосіб життя серед сільського жіноцтва, а також формувало начіональні иінності серед населення: любов до рідної мови, традицій, звичаїв, культури, батьківщини. Діяльність Союзу Украйнок та видання «Украйнка» набуло широкого розмаху у краї, тому польський окупаційний режим неодноразово конфісковував чергові числа та номери. Вагомість, вплив та роль видання «Українка» серед галицького населення значні, оскільки політична пропаганда проти ворожсої влади та украӥнська нащіональна ідея сприяли визвольній боротьбі українського народу.

Ключові слова: жіноча преса, Союз украӥнок, украӥнська начіональна ідея, начіональна свідомість, політична пропаганда, начіональні цінності.

Вступ. Союз українок як найбільша жіноча організація Галичини видавав кілька власних друкованих органів. Загальна риса цих часописів - статті, які формували національну свідомість українки. Таким видання Союзу українок для жінок патріотичного характеру в Галичині була «Українка», яка виходила протягом 1938 - 1939 років.

Постановка проблеми. «Українка» пропагувала національну ідею серед жіноцтва, поширювала пропаганду серед жіночих мас, формуючи у сільського жіноцтва національну свідомість, відчуття обов'язку перед своєю батьківщиною, любов до неї, збереження звичаїв та плекання рідної української мови. Видання називаємо політичним жіночим часописом, бо редакція не обмежувалася тільки обговоренням жіночих питань. На сторінках часопису надрукована велика кількість публікацій на політичну тематику. Пропаганда української національної ідеї була головною метою видання. Всі інші жіночі питання знаходилися на другому місці. Вивчення тематичного контенту важливе для аналізу політичної пропаганди видання, яке воно здійснювало проти окупаційної влади.

Мета наукової статті - здійснити огляд кількох номерів жіночого журналу «Українка», проаналізувати матеріали національного характеру, в яких пропагується українська національна ідея серед українського жіноцтва.

Методика дослідження. У статті використано низку наукових методів: функціональний (у аналізі ролі видання в загальних суспільно-політичних процесах Галичини); загальний аналіз розвитку жіночої періодики; синтез, хронологічний та типологічний наукові прийоми.

Бібліографічний покажчик видань Галичини містить коротку інформацію про видання як про популярний часопис Центрального товариства Союзу українок. «Українка» - пресовий орган Союзу 
українок. За періодичністю часопис був місячником і виходив обсягом до шістнадцяти сторінок. Формат видання невеликий. Серед завдань часопису - допомога сільському жіноцтву зростати патріотично, бо село повинне поширювати українську національну ідею. З'явилася «Українка» 1938 року за ініціативи Союзу українок як потреба жіночої організації у друкованому органі. «Союз українок видавав місячник «Українка» $(1938$ - 1939), що ставив собі за мету допомагати жінці. У виданні велася постійна рубрика «Як ми працюємо в кружках?», «Що діється у світі?» [4, с. 53].

Видання відкривалося програмною статтею «Наше слово», в якій редакція зробила огляд розвитку громадського жіночого руху. М. Рудницька написала звернення «До всього жіноцтва» [5], закликаючи жінок до єдності в збереженні народних традицій, звичаїв, «усього рідного». Часопис повідомляв про призупинення діяльності Союзу українок і створення політичної партії Дружина княгині Ольги.

Редагувала часопис Мілена Рудницька, яка проголосила українську національну ідею провідною тематикою у виданні. У редакційній статті першого числа «3 Новим Роком, з новим щастям» Мілена Рудницька характеризує значення і мету виходу часопису: «Радісну новину несемо Вам, 3 новим Роком. Вам усім, що станули в Кружках Союзу Українок до праці в користь Батьківщини. I Вам, що бажали б станути до діла, з'єднатись у службі Народові з іншими подібними Нам, та не знаєте, як до цього взятися. I нам усім, сестри українки, що живете узадушливому, заскленому, безпросвітному житті, за спільним радісним ділом, за громадською працею в дружньому жіночому колі. Усім вам призначений цей часопис» $[5, \mathrm{c.1}]$.

У публікації вказано, що потрібно вступати до Союзу українок і взятися до спільного діла служити своєму народові та Батьківщині. Тобто це і є пропаганда української національної ідеї для галицького жіноцтва - вищий ідеал, якому повинна служити українка. Видання формувало національно-патріотичною пропагандою новий тип українки- завзятої патріотки, яка готова боронити свій рідний край, а не жити у постійній задусі. Якщо проаналізувати бодай один номер видання, то можна переконатися, що політична тематика є провідною у часописі. Але поряд 3 тим, у часописі друкуються поезії молодих талановитих поетес, огляди 3 жіночого руху та жартівливі фейлетони.

Спочатку часопис не ставив собі за мету пропагувати українську національну ідею i поширювати їі в жіночі маси. Видання призначене, насамперед, для сільського жіноцтва, мало на меті допомогти сільській жінці у її важкій щоденній праці. Але уже в перших числах на сторінках «Українки» можна зустріти статті на політичну тематику, де гостро критикується діяльність польської влади і дискримінація українського населення. Головною проблемною темою «Українки» була тема українського шкільництва, яке польська влада намагалася знищити. На першому ж місці редакція вважала своїм обов'язком виховувати жінку у патріотичному і моральному дусі. Політична тематика не подобалася польській владі, яка конфіскувала значну частину матеріалів, а згодом заборонила вихід видання.

Важливо проаналізувати структуру видання. Наприклад, структура першого числа видання за 1938 рік. На першій сторінці надрукована вище згадана редакційна стаття-вітання Мілени Рудницької, де сформульовані засади, напрями і мета організованого жіноцтва. Стаття досить велика за обсягом і займає кілька сторінок. Далі надрукований короткий огляд, в якому згадані відомі жінки-патріотки: О. Пчілка, М. Вовчок, Г. Барвінок, Н. Кобринська як мужні жінки, які працювали для свого народу і які були ідеологами жіночого руху в Україні. Багато інформації часопис подавав про Наталю Кобринську як засновницю Жіночого руху в Україні.

На четвертій сторінці читач міг прочитати вірш відомої молодої поетеси Марії Підгір'янки про матір. Матір для авторів видання була у центрі уваги, бо саме матір формує світогляд дитини на ранніх етапах і від матері залежить, ким виросте дитина. Темі матері і дитини присвячена стаття Ліди Менї «Мати - перша виховниця дитини», де матір названо найважливішою особою для дитини. 3 піснею матері дитина починає любити українську пісню і засвоювати рідну мову, з колиски дитина починає шанувати свій народ та берегти звичаї. Мати в уявленні часопису повинна плекати у дитини цю любов, почуття патріотизму.

На наступній сторінці редакція розповідала своїм читачкам про чергову річницю свята Злуки «Свято 22-го січня» та про IV універсал проголошення самостійності України. Цей матеріал не сподобався польській владі за патріотичний дух, оскільки стаття несла ідею незалежності української нації. Ідея свободи, незалежності і суверенності української держави для авторів статті була мрією, політичним ідеалом. Тому більшість публікацій «Українки» наскрізь пронизані патріотизмом та національною ідеєю. 
На першій шпальті журналу автори друкували світлини українських поетів, наприклад, Лесі Українки чи Тараса Шевченка з нагоди річниць уродин чи смерті [6; 7]. Це була характерна особливість кожного номера. Поряд з розгорнутими матеріалами про відомих українців, автори намагалися донести до свого читача ідею національної боротьби за власну державу, що було прихованою національно-патріотичною i політичною пропагандою. Власне такі патріотичні матеріали постійно натикалися на гостру цензуру з боку окупаційної влади.

У першому числі знаходимо публікації гумористичного характеру, зокрема фейлетон. Фейлетон був одним із популярних жанрів тогочасної галицької преси. У фейлетонах, як правило, редакція дозволяла собі висміяти якесь негативне явище чи подію, людей. Наприклад, фейлетон «Як Настя 3 чоловіком будують хату» висміює жінок, які не хотіли добре господарювати, а ледачкували на печі. Фейлетони висміювали негативні політичні події, політику польської влади щодо українців. Жанр політичного фейлетону застосовувався у галицькій періодиці як гостра критика польської влади за антиукраїнську агресивну політику.

Традиційна рубрика часопису «Як працюємо в Кружках Союзу Українок» розташовувалася на дванадцятій сторінці. Редакція детально повідомляє про громадську роботу Союзу українок, критикує бездіяльність деяких членів організації. Інформація про діяльність Союзу українок бентежила владу, яка не могла ігнорувати національно-патріотичну пропаганду організації. Тому авторок - членів Союзу українок арештовували, а журнал з четвертого числа заборонили. Саме ця рубрика часопису демонструвала активну діяльність національно свідомого галицького жіноцтва.

Інформаційний блок новин розташовувався поряд із рекламою («Реклама і інформація»). Це були короткі невеликі замітки про новини в Україні, а також оголошення, реклама продажу виробів чи оголошення про мистецькі і публічні заходи інших організацій. У першому числі була інформація про те, що діється на Великій Україні. Матеріали інформаційного характеру, як правило, невеликі за обсягом. Головними новинами вважалися новини політичного характеру, оскільки галичан цікавило життя і побут своїх братів зі Східної України.

Рубрика міжнародного життя у першому числі видання «Що діється у світі?» повідомляла про важке становище українців у царській Росії. У часописі большевицька влада постає як близнюк царської влади, бо нічим не відрізняється від бажання володіння та керування українською нацією, тому для нашої нації несе лише гніт. Національна та політична пропаганди большевиками жорстоко придушується, а гніт для українців, що живуть на теренах Східної України такий великий, якого не бачив ще світ.

Наприклад, у другому числі, редакція подає ще одну нову рубрику «Щось для наших дівчат», в якій була надрукована інформація про відділи Кружка Союзу Українок: «У нашому Кружку поділена праця на різні відділи. Призначено вести відділ мистецтва, дбати про вишивки, про народний одяг» $[6$, с. 5]. У цій рубриці читачі можуть ознайомитися із структурою та обов'язками відділів, Кружків Союзу Українок, які діяли увсіх селах Галичини і проводили важливу просвітницьку роботи серед галицького населення.

Союз українок пропагував здоровий спосіб життя. Головною акцією 1938 року стала боротьба з алкоголізмом. Союз українок не міг стояти осторонь від цієї важливої проблеми, з якою стикається щодня жіноцтво. Редакція запровадила окрему рубрику «Здоровля наш скарб» [6], в якій друкувалися статті відомого медика-жінки Софії Парфанович. У багатьох статтях Софія Парфанович намагалася дати обгрунтовану відповідь про шкідливість тютюну та алкоголю для молодого, здорового організму. Саме у цій рубриці редакція не тільки пропагувала національну ідею; вона також пропагувала здоровий спосіб життя для того, щоб виховати і зберегти здорову українську націю, про що неодноразово йшлося у багатьох публікаціях часопису.

Публікації для сільських жінок заохочували їх до громадської роботи. Видання порушувало питання, пов'язані з українською школою, українською наукою. Редакція висвітлювала роботу товариств «Просвіта» і «Рідна школа»; у часописі обговорювалися питання професійної освіти. Після виходу чотирьох чисел часопис припинив своє існування через заборону польської влади. Через рік часопис знову почав виходити.

У першому числі нового 1939 року у редакційній статті «Зберігаймо наші старі звичаї!» Ірина Гургула пропагує любов до національного мистецтва. У цьому номері редакція друкує великий нарис Наталі Кобринської «Пробудження українського жіноцтва», у якому українська національна ідея постає як головний ідеал активного жіноцтва. Тому, згодом, за патріотичний дух видання знову було конфісковане та заборонене польською владою. Кілька номерів часопису «Українка», які вийшли у світ сколихнули галичан, оскільки політична і національно-патріотична пропаганди 
формували патріотичний настрій у галичан. Головною та наскрізною ідею часопису стала українська національна ідея як найвищий ідеал, до якого повинна прагнути українська нація.

Результати дослідження. Отже, перегляд першого числа і головних публікацій часопису свідчить про те, що видання пропагувало українську національну ідею як найвищий ідеал для українського суспільства. Публікації авторів пронизані гострою критикою політики антиукраїнської влади. Жанри часопису представлені статтями, нарисами, замітками, оглядами.

Висновки та перспективи подальших досліджень. Видання «Українка» за своє коротке існування підготувало жіноцтво до усвідомлення того, що жінка не повинна стояти осторонь політичних подій, що вона повинна виконати свій обов'язок перед Батьківщиною. Жіночий рух Галичини перейшов від громадської діяльності до політичної. Найвищим ідеалом стає служіння народові $є$ моральні цінності жінки. Патріотична пропаганда присутня майже у кожній політичній публікації редакції та українська національна ідея стає наскрізною і провідною ідеєю часопису «Українки». Тому сьогодні надзвичайно актуальним для України залишається тема Жіночого руху, діяльності Союзу Українок і статті часопису «Українка», які потрібно активно досліджувати.

\section{Бібліографічний список:}

1. Богачевська-Хом’як М. (1991). Союз українок у міжвоєнний період. Наше життя. Ч. 2. С. 4-7. (in Ukraine).

2. Передирій В. А. (1993). Часописи «Союзу Українок» і національно-визвольний рух у Галичині (1922-1939). Українська періодика: Історія і сучасність. Львів. С. 64-68. (in Ukraine).

3. Передирій В. А. (1996). Українські періодичні видання для жінок в Галичині (1853-1939рp.) : Анотований каталог. Львів. 191 с. (in Ukraine).

4. Передирій В. А. (1995). Галицька періодика для жінок: становлення, розвиток, проблематика (1853 - 1939 рр.). Збірник праць науково-дослідного центру періодики. Вип. 2. С. 44-63. (in Ukraine).

5. Українка. Ч. 1. 1938. (in Ukraine).

6. Українка. Ч. 2. 1938. (in Ukraine).

7. Українка. Ч. 1. 1939. (in Ukraine).

\section{References:}

1. Bohachevs'ka-Khom'yak M. (1991). Soyuz ukrayinok u mizhvoyennyy period. Nashe zhyttya. N. 2. S. 4-7. (in Ukraine).

2. Peredyriy V. A. (1993). Chasopysy «Soyuzu Ukrayinok» i natsional'no-vyzvol'nyy rukh u Halychyni (1922-1939). Ukrayins'ka periodyka: Istoriya i suchasnist'. L’viv. S. 64-68. (in Ukraine).

3. Peredyriy V. A. (1996). Ukrayins'ki periodychni vydannya dlya zhinok v Halychyni (1853-1939 rr.) : Anotovanyy kataloh. L’viv. 191 s. (in Ukraine).

4. Peredyriy V. A. (1995). Halyts'ka periodyka dlya zhinok: stanovlennya, rozvytok, problematyka (1853 - 1939 rr.). Zbirnyk prats' naukovo-doslidnoho tsentru periodyky. Vyp. 2. S. 44-63. (in Ukraine).

5. Ukrayinka. N. 1. 1938. (in Ukraine).

6. Ukrayinka. N. 2. 1938. (in Ukraine).

7. Ukrayinka. N. 1. 1939. (in Ukraine).

\section{Pavlyuh M. V. Political promotion and the ukrainian national idea in the journal "Ukrainka»}

The main topic, genres, articles of the magazine of the Ukrainian Union «Ukrainka» are analyzed. Materials in which women promoted the national idea and formed the national consciousness were investigated. The main thematic content of the patriotic edition is highlighted. The organization of the work of the editorial staff was studied: columns and departments. The main publications in which the authors of the articles carried out political propaganda against the Polish occupation authorities are presented. It is found that the publication of the Ukrainian Union «Ukrainka» shaped female patriotism, aroused political consciousness. The main directions of activity of the women's patriotic organization of the Union of Ukrainians, which operated in Galicia in the first half of the twentieth century, are indicated.

The Ukrainian national idea became a cross-cutting idea for the magazine. The body of the patriotic Ukrainian women's organization of the Union of Ukrainians played an important role in the political life of Galicia in the first half of the twentieth century, as it united patriotic women in the struggle for political freedoms. The activity of the woman-mother, the woman-guardian of the family hearth, the woman-patriot was supported by the publication as the main ideological component of many articles. Political propaganda in the front pages of «Ukrainka» magazine formed public opinion, first of all, of rural women, who were not always able to read and learn.

The article analyzes several important publications that demonstrate the main thematic areas. The «Ukrainka» promoted healthy lifestyles among rural women, and also shaped national values among the 
population: love of mother tongue, traditions, customs, culture, and homeland. The activities of the Union of Ukrainians and the edition of Ukrainka have become widespread in the country, so the Polish occupation regime has repeatedly confiscated regular numbers and numbers. The importance, influence and role of «Ukrainka» among the Galician population are significant, as political propaganda against hostile authorities and the Ukrainian national idea contributed to the liberation struggle of the Ukrainian people.

Key words: women's press, Ukrainian women's union, Ukrainian national idea, national consciousness, political propaganda, national values. 